\title{
Renin-angiotensin-aldosterone system blockers after KDIGO stage 3 acute kidney injury: use and impact on 2-year mortality in the AKIKI trial
}

\author{
Mathilde Scarton ${ }^{1 \dagger}$, Anne Oppenheimer ${ }^{2,3{ }^{\dagger}}$, Khalil Chaïbi ${ }^{1}$, Didier Dreyfuss ${ }^{1}$ and Stéphane Gaudry ${ }^{4,5,6^{*}}$ (D)
}

\section{Dear Editor,}

Acute kidney injury (AKI) carries high mortality and morbidity $[1,2]$. Two studies recently suggested the potential benefit of renin-angiotensin system (RAS) blockers (angiotensin-converting enzyme inhibitors (ACEIs) and angiotensin receptor blockers (ARBs)) after AKI $[3,4]$. The first one reported a lower mortality after 1 year of follow-up in patients receiving an ACEi or ARB after an episode of AKI (KDIGO stages 1 to 3) at ICU discharge (20/109 (18\%) vs 153/502 (31\%), $p=0.001)$ [3]. The second one was a retrospective cohort study including adults after an episode of AKI during hospital stay (with $18 \%$ only of ICU-patients and only $7 \%$ of KDIGO stage 3) [4]. It concluded that exposure to an RAS blocker within the first 6 months after hospital discharge was associated with a $15 \%$ decrease in all-cause mortality (HR, 0.85; 95\%CI, 0.81-0.89).

We performed an ancillary of the AKIKI trial [5], which included 619 ICU patients with severe AKI
(KDIGO stage 3) in order to evaluate the potential effect of RAS blockers on long-term mortality.

All patients discharged alive from ICU were included, and their long-term prognosis (2-year all-cause mortality) was assessed according to treatment with ACEi/ARB at ICU discharge using both univariate and multivariate analyses.

Among 348 patients discharged alive from ICU, 45 (12.9\%) received an ACEi/ARB at ICU discharge (see Table 1 for patient characteristics). Patients without ACEi/ARB were more severe as attested by a higher SAPS $3(p=0.02)$ and a higher rate of catecholamine infusion $(p=0.008)$ during AKI. However, 2-year all-cause mortality did not significantly differ between the two groups (12/45 (27\%) with ACEi/ARB vs $55 / 303(18 \%)$ without, $p=0.18)$. Mortality risk was not associated with non-prescription of ACEi/ ARB after adjustment for prognostic variables $(p=$ 0.21) (Table 2).

\footnotetext{
* Correspondence: stephanegaudry@gmail.com

${ }^{\dagger}$ Mathilde Scarton and Anne Oppenheimer contributed equally to this work.

${ }^{4}$ AP-HP, Service de Réanimation Médico-Chirurgicale, Hôpital Avicenne, 93000 Bobigny, France

${ }^{5}$ French National Institute of Health and Medical Research (INSERM),

UMR_S1155, Remodeling and Repair of Renal Tissue, Hôpital Tenon, F-75020

Paris, France

Full list of author information is available at the end of the article
}

(c) The Author(s). 2019 Open Access This article is distributed under the terms of the Creative Commons Attribution 4.0 International License (http://creativecommons.org/licenses/by/4.0/), which permits unrestricted use, distribution, and

reproduction in any medium, provided you give appropriate credit to the original author(s) and the source, provide a link to the Creative Commons license, and indicate if changes were made. The Creative Commons Public Domain Dedication waiver (http://creativecommons.org/publicdomain/zero/1.0/) applies to the data made available in this article, unless otherwise stated. 
Table 1 Patient characteristics

\begin{tabular}{|c|c|c|c|}
\hline & $\begin{array}{l}\text { ACEi/ARB + } \\
(N=45)\end{array}$ & $\begin{array}{l}\text { ACEi/ARB - } \\
(N=303)\end{array}$ & $p$ \\
\hline \multicolumn{4}{|l|}{ Characteristic at ICU admission } \\
\hline Age-years & $64.4 \pm 15.1$ & $63.1 \pm 14.7$ & 0.6 \\
\hline Male sex-no. (\%) & $32(71)$ & $193(63)$ & 0.3 \\
\hline Weight—kg & $85.8 \pm 23.7$ & $82.4 \pm 20.5$ & 0.3 \\
\hline \multicolumn{4}{|l|}{ Main reason for ICU admission—no. (\%) } \\
\hline Medical & $37(82)$ & $263(87)$ & \\
\hline Surgical, emergency & $5(11)$ & $66(22)$ & \\
\hline Surgical, scheduled & $3(7)$ & $19(6)$ & \\
\hline $\begin{array}{l}\text { Serum creatinine before } \\
\text { ICU admission }\end{array}$ & $92.0 \pm 24.7$ & $83.4 \pm 24.0$ & 0.03 \\
\hline \multicolumn{4}{|l|}{ Coexisting condition-no. (\%) } \\
\hline Chronic renal failure & $6(13)$ & $26(9)$ & 0.3 \\
\hline Hypertension & $28(62)$ & $152(50)$ & 0.1 \\
\hline Diabetes mellitus & $3(7)$ & $31(10)$ & 0.67 \\
\hline Congestive heart failure & $6(13)$ & $17(6)$ & 0.05 \\
\hline Ischemic heart disease & $8(18)$ & $26(9)$ & 0.05 \\
\hline SAPS III at ICU admission & $63.0 \pm 14.0$ & $68.3 \pm 14.3$ & 0.02 \\
\hline Septic shock—no. (\%) & $26(58)$ & $128(42)$ & 0.05 \\
\hline \multicolumn{4}{|l|}{ Biological characteristics } \\
\hline Serum creatinine $-\mu \mathrm{mol} / \mathrm{L}$ & $203.9(133.1)$ & $219.6(136.9)$ & 0.47 \\
\hline Blood urea nitrogen $-\mathrm{mmol} / \mathrm{L}$ & $13.0(8.4)$ & $14.4(9.3)$ & 0.34 \\
\hline Serum potassium—mmol/L & $4.1(0.8)$ & $4.3(0.9)$ & 0.37 \\
\hline Serum bicarbonate-mmol/L & $19.9(5.0)$ & $18.7(5.7)$ & 0.17 \\
\hline \multicolumn{4}{|l|}{ Characteristic of ICU stay } \\
\hline \multicolumn{4}{|c|}{ Physiological support during ICU stay—no. (\%) } \\
\hline Invasive mechanical ventilation & $41(91)$ & $260(86)$ & 0.33 \\
\hline $\begin{array}{l}\text { Vasopressor support } \\
\text { (epinephrine or norepinephrine) }\end{array}$ & $31(69)$ & $257(85)$ & 0.008 \\
\hline $\begin{array}{l}\text { Number of patients who } \\
\text { received RRT—no. (\%) }\end{array}$ & $28(62)$ & $211(70)$ & 0.32 \\
\hline Ventilator duration—median (IQR) & $5(5-13)$ & $5(4-10)$ & 0.40 \\
\hline Vasopressor-free days-median (IQR) & $3(2-5)$ & $4(2-7)$ & 0.11 \\
\hline Length of ICU stay-median (IQR) & $18(11-20)$ & $15(8-22)$ & 0.35 \\
\hline \multicolumn{4}{|l|}{ RRT dependence-no. (\%) } \\
\hline At day 28 & $4(9)$ & $27(9)$ & 0.99 \\
\hline At day 60 & $1(2)$ & $9(3)$ & 0.77 \\
\hline \multicolumn{4}{|l|}{ Mortality—no. (\%[95\% CI]) } \\
\hline At day 60 & $6(13)$ & $39(12)$ & 0.73 \\
\hline Creatinine at ICU discharge & $183.6 \pm 136.4$ & $177.9 \pm 150.1$ & 0.81 \\
\hline
\end{tabular}

$A C E i$ angiotensin-converting enzyme inhibitors, $A R B$ angiotensin receptor blockers, ICU intensive care unit, IQR interquartile range, $R R T$ renal replacement therapy, $\mathrm{Cl}$ confidence interval

We acknowledge that our study did not assess introduction nor interruption of ACEi/ARB after ICU discharge. One consequence of the severity of AKI in our
Table 2 Multivariate analysis

\begin{tabular}{llll}
\hline Variable & OR & $95 \% \mathrm{Cl}$ & $p$ \\
\hline Age & 1.02 & {$[1.00-1.05]$} & 0.04 \\
MacCabe & 3.10 & {$[1.64-5.87]$} & $<0.001$ \\
SAPS3 & 1.04 & {$[1.02-1.07]$} & $<0.01$ \\
CKD & 1.99 & {$[0.77-4.89]$} & 0.14 \\
Congestive heart failure & 2.12 & {$[0.66-6.43]$} & 0.19 \\
History of acute stroke & 1.91 & {$[0.80-4.38]$} & 0.13 \\
ACEi/ARB at ICU discharge & 1.71 & {$[0.71-3.90]$} & 0.21 \\
\hline
\end{tabular}

CKD chronic kidney disease

study is that most patients had not fully recovered at ICU discharge. In this condition, physicians in charge could be reluctant to initiate ACEi/ARB in ICU but treated the patients later.

Our study does not confirm findings from two recent studies $[3,4]$. This discrepancy could be explained by a different population (less severe AKI in previous studies) and/or a lack of power of our study but in any case warrant the performance of a randomized controlled trial of ACEi/ARB at ICU discharge after an episode of severe AKI.

\section{Abbreviations}

ACEls: Angiotensin-converting enzyme inhibitors; AKI: Acute kidney injury; ARBs: Angiotensin receptor blockers; ICU: Intensive care unit; KDIGO: Kidney Disease Improving Global Outcomes; RAS: Renin-angiotensin system

\section{Acknowledgements}

We thank patients and their surrogates who participated to AKIKI trial. We thank all medical and nurses teams from all study sites of AKIKI.

\section{Funding}

This study was supported by a grant from the Programme Hospitalier de Recherche Clinique National, 2012 (AOM12456), funded by the French Ministry of Health.

\section{Availability of data and materials}

The datasets used and/or analyzed during the current study are available from the corresponding author on reasonable request.

\section{Authors' contributions}

$\mathrm{SG}, \mathrm{DD}$, and $\mathrm{MS}$ conceived the study. $\mathrm{AO}$ and $\mathrm{KC}$ managed the data. $\mathrm{AO}$ performed the statistical analysis. SG, MS, and AO drafted the manuscript. All authors contributed substantially to the revision. All authors read and approved the final manuscript.

\section{Ethics approval and consent to participate}

The original trial was approved by the ethical committee of the French Society of Intensive Care Medicine and by the competent French legal authority (Comité de Protection des Personnesd'lle de France VI, ID RCB 2013-A00765-40, NCT01932190) for all participating centers. According to French law, because the treatments and strategies used in the study were classified as standard care, there was no requirement for signed consent, but the patients or next of kin were informed about the study before enrolment and confirmed this fact in writing.

\section{Consent for publication}

Not applicable.

Competing interests

The authors declare that they have no competing interests. 


\section{Publisher's Note}

Springer Nature remains neutral with regard to jurisdictional claims in published maps and institutional affiliations.

\section{Author details}

'AP-HP, Service de Réanimation Médico-Chirurgicale, Hôpital Louis Mourier, F-92700 Colombes, France. ${ }^{2}$ Service de Médecine de la Reproduction et Préservation de la fertilité, Hôpital Universitaire Antoine Béclère, Clamart, France. ${ }^{3}$ EA 7285 Research Unit 'Risk and Safety in Clinical Medicine for Women and Perinatal Health', Versailles-Saint-Quentin University (UVSQ), Versailles, France. ${ }^{4}$ AP-HP, Service de Réanimation Médico-Chirurgicale, Hôpital Avicenne, 93000 Bobigny, France. ${ }^{5}$ French National Institute of Health and Medical Research (INSERM), UMR_S1155, Remodeling and Repair of Renal Tissue, Hôpital Tenon, F-75020 Paris, France. ${ }^{6}$ Present Address: Intensive Care Unit, Hôpital Avicenne, 125 Rue de Stalingrad, 93000 Bobigny, France.

Received: 8 April 2019 Accepted: 16 April 2019

Published online: 29 April 2019

\section{References}

1. Fortrie G, de Geus HRH, Betjes MGH. The aftermath of acute kidney injury: a narrative review of long-term mortality and renal function. Crit Care. 2019; 23(1):24.

2. Mehta RL, Kellum JA, Shah SV, Molitoris BA, Ronco C, Warnock DG, et al. Acute Kidney Injury Network: report of an initiative to improve outcomes in acute kidney injury. Crit Care. 2007:11(2):R31.

3. Gayat E, Hollinger A, Cariou A, Deye N, Vieillard-Baron A, Jaber S, et al. Impact of angiotensin-converting enzyme inhibitors or receptor blockers on post-ICU discharge outcome in patients with acute kidney injury. Intensive Care Med. 2018;44(5):598-605.

4. Brar S, Ye F, James MT, Hemmelgarn B, Klarenbach S, Pannu N, et al. Association of angiotensin-converting enzyme inhibitor or angiotensin receptor blocker use with outcomes after acute kidney injury. JAMA Intern Med. 2018;178(12):1681-90

5. Gaudry S, Hajage D, Schortgen F, Martin-Lefevre L, Pons B, Boulet E, et al. Initiation strategies for renal-replacement therapy in the intensive care unit. N Engl J Med. 2016;375(2):122-33.

Ready to submit your research? Choose BMC and benefit from:

- fast, convenient online submission

- thorough peer review by experienced researchers in your field

- rapid publication on acceptance

- support for research data, including large and complex data types

- gold Open Access which fosters wider collaboration and increased citations

- maximum visibility for your research: over $100 \mathrm{M}$ website views per year

At $\mathrm{BMC}$, research is always in progress.

Learn more biomedcentral.com/submissions 